DOI: https://doi.org/10.24144/2409-6857.2018.2(52).218-222

УДК 657

Голик В.P.

\title{
ЕКОЛОГІЧНИЙ ОБЛІК ЯК СКЛАДОВА УПРАВЛІННЯ ПІДПРИЄМСТВОМ
}

\begin{abstract}
Екологічні аспекти, в тому числі зростаючі екологічні витрати, здійснюють суттєвий вплив на економічну діяльність суб'єкта господарювання $i$, як наслідок, вони потребують інституціоналізаиії в рамках системи бухгалтерського обліку в иңілому, і управлінського обліку, зокрема, щзо означає поява $i$ впровадження екологічного обліку. Необхідність розгляду екологічних питань управлінської системи як складової частини облікових прочесів суб'єктів господарювання зумовлена відсутністю системності, наявності роз'яснень облікової термінологї, комплексної методики екологізації обліку, вимог до розкриття екологічної інформачії у звітності. В статті окреслено сучасні проблеми екологічного обліку. Визначено сутність екологічного обліку як систематизації фінансової та нефінансової інформації $з$ метою оптимізації екологічної та економічної діяльності компанії $і$ забезпечення стійкості бізнесу. Здійснено дослідження оцінки типів управління екологічною діяльністю. Виділено чотири типи управління: управлінн, орієнтоване на виконання державних стандартів, превентивне управління (ефективне управління), стратегічне екологічне управління (екологічна концепція управління), управління сталим розвитком (активне управління). Запропоновано порядок побудови екологічного обліку.
\end{abstract}

Ключові слова: екологія, бухгалтерський облік, управлінський облік, екологічний облік, управління, інтеграція, превентивне управління, стратегічне екологічне управління, управління сталим розвитком.

Постановка проблеми. Екологічні проблеми та їх негативний вплив на людство і катастрофічні наслідки є питанням, яке постійно стоїть на порядку денному. Здійснюється пошук напрямків розвитку суспільства, які б враховували природно-екологічну рівновагу. Одним із основних інструментів, покликаним вирішити дану проблему на рівні господарюючого суб'єкта, $є$ наукова розробка i постановка екологічного обліку. В даний час при регулюванні фінансового обліку i фінансової звітності екологічні аспекти відображаються в деякій мірі безсистемно, за відсутності роз'яснень облікової термінології, комплексної методики екологізації обліку, вимог до розкриття екологічної інформації у звітності. Звідси виникає необхідність розгляду екологічних питань управлінської системи як складової частини облікових процесів суб'єктів господарювання.

Аналіз останніх досліджень і публікацій. Дослідженнями екологічного обліку у системі управління підприємством займалися такі науковці: I.Н Губайдуліна, В.О. Ганусич, Т.Н. Гоголева, І. В. Замула, С.В. Ільїчева, Т.А. Керсанова, Л.М. Пелиньо, Н.М. Рубанова, К.С. Саєнко. Враховуючи значну кількість досліджень сутності облікових процесів екологічних питань, залишаються невирішеними питання місця екологічного обліку в системі управління, що багато в чому обумовлено дискусійним характером думок про сутність екологічного обліку, його предмет

(C) Голик Василь Романович, аспірант КНЕУ ім.. В. Гетьмана, м. Київ, Україна, тел.:+380503720720, e-mail: vasya.holyk.uz@gmail.com об'єкт, методи тощо.

Формулювання цілей статті. Метою дослідження $\epsilon$ визначення сутності екологічного обліку в системі управління та вплив обраної екологічної політики компанії на обліковий процес вцілому.

Виклад основного матеріалу дослідження.

Екологічні аспекти, в тому числі зростаючі екологічні витрати, здійснюють суттєвий вплив на економічну діяльність суб'єкта господарювання i, як наслідок, вони потребують інституціоналізації в рамках системи бухгалтерського обліку в цілому, і управлінського обліку, зокрема, що означає поява і впровадження екологічного обліку.

Наразі наявні дискусійні моменти серед науковців щодо трактування сутності екологічного обліку та його місця в системі управління підприємством.

Зокрема, Т.А. Кірсанова, під екологічним обліком розуміс систему виявлення, вимірювання, реєстрації, нагромадження, узагальнення, зберігання, оброблення та підготовки релевантної інформації про діяльність підприємства в галузі природокористування 3 метою передачі іiі внутрішнім і зовнішнім користувачам для прийняття оптимальних рішень[5].

К.С. Саєнко [8] наводить наступне визначення екологічного обліку як впорядкованої системи збору, реєстрації та узагальнення інформації в натуральному i грошовому вираженні про природні ресурси, екологічних зобов'язання, господарські операції природоохоронної 
діяльності організації шляхом суцільного, безперервного документального обліку природокористування господарюючого суб'єкта.

Е.В. Іллічова [4] розглядає екологічний облік як сегментарну область бухгалтерського обліку, представлену в вигляді системи збору, реєстрації та узагальнення інформації, яка забезпечить можливість виявлення, оцінки, планування та прогнозування, контролю і аналізу екологічних витрат і екологічних зобов'язань.

Т.Н. Гоголєва [2] екологічний облік визначає як формування документованої систематизованої інформації про екологічну діяльності економічного суб'єкта відповідно до вимог до облікової інформації і складання на іiї основі екологічної звітності.

На думку Н.М. Рубанової [7] екологічний облік - це процес збору, реєстрації, узагальнення і відображення в системі природоохоронних витрат, природних активів, екологічних фондів, резервів і зобов'язань, а також результатів діяльності господарюючих суб'єктів 3 метою управління та визначення екологічного потенціалу підприємства.

Погоджуємось із точкою Л.М. Пелиньо [6], що екологічний облік має мати місце в загальній системі облікового процесу на підприємстві, тільки у цьому випадку він стане ефективним інструментом екологічної діяльності на підприємстві.

У наведених визначеннях екологічного обліку простежується загальний підхід до того, що це $\epsilon$ системи збору, реєстрації та узагальнення інформації екологічного характеру. Перед обліковою системою постає проблема інтеграції екологічного обліку. Вважаємо, що відповідно до нових інтеграційних підходів екологічний облік повинен стати частиною єдиного інформаційного простору бухгалтерського комплексу економічного суб'єкта як одна з підсистем бази управління 3 фінансовими i нефінансовими показниками.

Огляд дефініцій екологічного обліку дозволяе представити уточнене його визначення. Екологічний облік - це систематизація фінансової та нефінансової інформації з метою оптимізації екологічної та економічної діяльності компанії і забезпечення стійкості бізнесу.

Інформація, надана екологічним обліком, може бути використана для будь-якого типу управлінської діяльності в рамках організації, але особливо вона корисна там, де присутній певний екологічний компонент.

На основі такої інформації керівники можуть управляти, а працівники усвідомлюють фактичні та потенційні економічні наслідки екологічних аспектів.

Систематичне використання принципів екологічного обліку сприяе ідентифікації екологічних витрат, прихованих у традиційному обліку, у більш точному співвідношенні екологічних витрат з продуктами, у визначенні надходжень (наприклад, від економії енергії при використанні енергозберігаючого обладнання), у прийнятті рішень щодо інвестицій у природоохоронні заходи, у використанні нефінансової інформації, пов'язаної 3 навколишнім середовищем.

Екологічний облік формує основу для досягнення цілей організації. Так, якщо ціль ставиться зменшення відходів виробничої сировини за певним відсотком, то система управлінського обліку дасть інформацію по цільових показниках, фактичних результатах та їх співвідношеннях. Екологічний облік, у свою чергу, створює зворотний зв'язок і діє як механізм контролю, забезпечуючи підзвітність та відповідальність персоналу. Коли виявляється розбіжність між цілями та фактично досягнутим рівнем, управлінський облік дозволяе скласти детальні звіти за відхиленнями, щоб працівники, відповідальні за ці відхилення, могли вжити відповідних заходів.

Відсутність єдиного стандарту формування інформації про природоохоронну діяльність зобов'язує господарюючі суб'єкти самостійно вибирати напрями та форми подання такої інформації: при складанні звітності включати додаткові показники та пояснення щодо своєї екологічної діяльності у сфері раціонального природокористування, охорони навколишнього середовища та екологічної безпеки 3 метою підвищення iї прозорості та якості інформації. Особливо істотним це є для підприємств, що здійснюють вплив на стан навколишнього середовища як позитивно, так і негативно.

Побудова екологічного обліку на підприємстві в системі управління на пряму буде залежати від прийнятої підприємством стратегічної екологічної політики (табл.1).

Управління, орієнтоване на виконання державних стандартів передбачає пасивне управління. Управлінський екологічний облік, в даному випадку, буде складатись 3 обліку екологічних витрат і обліку екологічних доходів як складової частини фінансового обліку. Якщо на підприємстві масштаби природоохоронної діяльності невеликі, ця діяльність структурно не відособлена, то облік екологічних витрат доцільно вести у розрізі рахунків 8-го класу на 
Таблиця 1.

Кластеризація екологічної стратегії управління підприємством та її вплив на побудову екологічного обліку *

\begin{tabular}{|c|c|c|c|}
\hline $\begin{array}{c}\text { № } \\
\text { II/II }\end{array}$ & $\begin{array}{c}\text { Тип } \\
\text { (сценарії) } \\
\text { управління }\end{array}$ & Діяльність підприємства & Екологічний облік \\
\hline 1 & $\begin{array}{l}\text { Управління, } \\
\text { орієнтоване } \\
\text { на виконання } \\
\text { державних } \\
\text { стандартів } \\
\text { (пасивне } \\
\text { управління) }\end{array}$ & $\begin{array}{l}\text { 1.Очистка відходів, викидів, захоронення відходів в } \\
\text { кінці виробничо-технологічного циклу } \\
\text { 2.Дотримання процедур зниження забруднення } \\
\text { 3.Дотримання процедур формування зовнішньої } \\
\text { екологічної звітності } \\
\text { 4. Наявність екологічної служби } \\
\text { 5. Прийняття екстрених мір. }\end{array}$ & $\begin{array}{ll}\text { Облік окремих } & \text { екологічних } \\
\text { витрат, доходів, формування } \\
\text { зовнішньої } & \text { екологічної } \\
\text { звітності } & \end{array}$ \\
\hline 2. & $\begin{array}{l}\text { Превентивне } \\
\text { управління } \\
\text { (ефективне } \\
\text { управління) }\end{array}$ & $\begin{array}{l}\text { 1 Внутрішній екологічний аудит } \\
\text { (різних типів і спрямованості). } \\
\text { 2. Запобігання забрудненню шляхом заміни } \\
\text { технології, сировини тощо. } \\
\text { 3.Мінімізація відходів. } \\
\text { 4. Скорочення енергоємності продукції. } \\
5 \text { Зниження рівня фізичних забруднень. } \\
\text { 6. Інформування громадськості про екологічно } \\
\text { значимі господарські рішення. } \\
\text { 7. Відповідальність менеджерів в підрозділах за } \\
\text { дотримання параметрів екологічності }\end{array}$ & $\begin{array}{l}\text { Створення системи } \\
\text { екологічного обліку (облік } \\
\text { екологічних витрат, доходів, } \\
\text { зобов'язань, формування } \\
\text { екологічної звітності тощо.) }\end{array}$ \\
\hline 3. & $\begin{array}{l}\text { Стратегічне } \\
\text { екологічне } \\
\text { управління } \\
\text { (Екологічна } \\
\text { концепція } \\
\text { управління) }\end{array}$ & $\begin{array}{l}\text { 1. Розвиток екологічного маркетингу } \\
\text { 2. Рівноправний діалог з громадськістю і } \\
\text { споживачами. } \\
\text { 3. Впровадження програм екологічної сертифікації } \\
\text { товарів і послуг. } \\
\text { 4. Надання повного обсягу екологічної значущої } \\
\text { інформації } \\
\text { 5. Створення системи «життєвий цикл» продукції і } \\
\text { утилізації } \\
\text { 6. Облік екологічно значимих зобов’язань в } \\
\text { інвестиційно-проектному циклі. }\end{array}$ & $\begin{array}{l}\text { Функціонування системи } \\
\text { екологічного обліку, } \\
\text { зовнішній екологічний аудит }\end{array}$ \\
\hline 4. & $\begin{array}{l}\text { Управління } \\
\text { сталим } \\
\text { розвитком } \\
\text { (активне } \\
\text { управління) }\end{array}$ & $\begin{array}{l}\text { 1. Стратегія підприємства в процесі сталого розвитку } \\
\text { 2. Визнання ролі підприємства в потоках товарів, } \\
\text { сировини, енергї } \\
\text { 3.Відповідність політики по відношенню до етики } \\
\text { «екологічно чистої» збутової діяльності, зміни } \\
\text { клімату, економії ресурсів тощо } \\
\text { 4.Відповідність екологічним стандартам на } \\
\text { міжнародних ринках } \\
\text { 5.Відображення концепції сталого розвитку у } \\
\text { звітності підприємства. }\end{array}$ & $\begin{array}{l}\text { Функціонування системи } \\
\text { екологічного обліку в системі } \\
\text { управління } \\
\text { підприємством. Міжнародний } \\
\text { аудит }\end{array}$ \\
\hline
\end{tabular}

* Побудовано за джерелами [1,3]

рахунку "Екологічна діяльність" 3 виділенням необхідних для аналітики субрахунків.

Превентивне управління (ефективне управління) передбачає створення системи екологічного обліку як складової частини облікового процесу на підприємстві в цілому.

На галузевих підприємствах із значним обсягом екологічної діяльності, що мають спеціалізовані цехи, надають іншим підприємствам екологічні послуги, доцільно, на нашу думку, ввести окремі рахунки по екологічній діяльності по кожному об'єкту обліку.

Стратегічне екологічне управління (Еколо- гічна конщепиія управління). Керівники сучасних організацій повинні приймати рішення і діяти як в інтересах самої організації, так і суспільства. Якщо керівники будуть притримуватися цієї позиції, зміниться суть процесу прийняття рішень та контролю, а, отже, і роль екологічного обліку в системі управління. Контроль з боку зацікавлених осіб (суб'єктів суспільного інтересу) може впливати на діяльність підприємства. Компанії 3 більшим бажанням будуть проявляти екологічну відповідальність, якщо в їх середовищі існують приватні незалежні організації, громадські рухи, інституційні інвестори та преса, що стежать за 
поведінкою компаній і мобілізуються для зміни їх поведінки. Функціонування системи екологічного обліку на підприємстві буде містити пріоритетний напрям становлення та розвитку. Суб'єкти суспільного інтересу будуть зацікавлені у зовнішньому незалежному екологічному аудиті.

Управління сталим розвитком (активне управління) передбачає соціальні, політичні, економічні, нормативні інституції, які впливають на екологічну відповідальність бізнесу. Так, рівень вимог суспільства до процесу «очищення» буде визначатися, наскільки підприємство конкретної галузі здатне забруднювати навколишнє середовище. В межах однієї галузі компаній піддаються різному рівні інституціонального тиску. Наприклад, транснаціональні корпорації часто мають більш високі стандарти соціальної та екологічної відповідальності, ніж національні компанії, оскільки вони відчувають додатковий тиск зацікавлених осіб іноземних держав. Оскільки саме навколишнє середовище надає сировину та енергію, необхідну для виробництва, екологічний аспект, такий як споживчі ресурси і забруднення землі, води та повітря, повинен бути включений в управлінський екологічний облік компаній. Більш того, компанії повинні бути готові до швидких змін у навколишньому середовищі та розвивати продукти і послуги, екологічно сумісні в майбутньому. Суб'єкти суспільного інтересу будуть зацікавлені у міжнародному екологічному аудиті.

Висновки i перспективи подалыших досліджень. Отже, проведене дослідження дозволило здійснити огляд дефініцій екологічного обліку та запропонувати власне трактування: екологічний облік - це систематизація фінансової та нефінансової інформації з метою оптимізації екологічної та економічної діяльності компанії і забезпечення стійкості бізнесу.

Побудова екологічного обліку на підприємстві в системі управління на пряму буде залежати від прийнятої підприємством стратегічної екологічної політики.

Нами розглянуто чотири сценарії управління екологічною діяльністю на підприємстві: управління, орієнтоване на виконання державних стандартів, превентивне управління (ефективне управління), стратегічне екологічне управління (екологічна концепція управління), управління сталим розвитком (активне управління) та окреслено умови побудови екологічного обліку на підприємствах.

Перспективним напрямком $\epsilon$ дослідження оцінки ефективності екологічного обліку в системі управління.

\section{ПЕРЕЛІК ВИКОРИСТАНИХ ДЖЕРЕЛ}

1. Ахмедьярова М.В., Баймуханова С.Б. Экологически ориентированное управление предприятием - главный ориентационный принцип перехода на модель устойчивого развития и повышения качества жизни [Электронный pесурс]. - Вестник КазНУ. - Алмата. 2012. - Режим доступа: https://articlekz.com/article/8419

2. Гоголева Т.Н., Бахтурина Ю.И. Экологический учет в системе видов учета / Т.Н. Гоголева, Ю.И. Бахтурина // Международный бухгалтерский учет. - 2015. - Вып.3(345). - С.2-13.

3. Губайдуллина И.Н., Ишмеева А.С. Экологический учет как фактор экономической безопасности хозяйствующего субъекта // Современные проблемы науки и образования. - 2015. - № 1-1.

4. Ильичева Е.В. Сравнительная характеристика финансового, налогового, управленческого и экологического учета // Фундаментальные исследования. 2009. № 1. С. 66-67.

5. Кирсанова Т.А., Кирсанова Е.В., Лукьянихин В.А. Екологический контроллинг - инструмент екоменеджмента/ Под ред. В.А. Лукьянихина. - Сумы: Изд-во "Козацький вал", 2004.

6. Пелиньо Л.М. Місце екологічного обліку в сучасній системі бухгалтерського обліку та його важливе значення в сфері охорони довкілля / Л.М. Пелиньо // Науковий вісник НЛТУ України. — 2008. — Вип. 18.2. — C. $70-75$.

7. Рубанова, Наталья Николаевна Экологический учет на предприятиях промышленности строительных материалов дис. ... канд.. эк. наук: 08.00.12/ Рубанова, Наталья Николаевна . - Ставрополь, 2005. - 176 с.

8. Саенко К.С. Учет экологических затрат. М.: Финансы и статистика, 2005. 376 с.

\section{REFERENCES}

1. Akhmed'yarova, M.V., \& Baymukhanova, S.B. (2012). Ekologicheski oriyentirovannoye upravleniye predpriyatiyem - glavnyy oriyentatsionnyy printsip perekhoda na model' ustoychivogo razvitiya i povysheniya kachestva zhizni [Ecologically oriented enterprise management as the main orientation principle of the transition to a model of sustainable development and improvement the quality of life]. Vestnik KazNU - Bulletin of KazNU. Retrieved from: https://articlekz.com/article/8419 [in Russian].

2. Gogoleva, T.N., \& Bakhturina, Yu.I. (2015). Ekologicheskiy uchet v sisteme vidov ucheta [Ecological accounting in the system of accounting types]. Mezhdunarodnyy bukhgalterskiy uchet - International accounting, 3(345), 2-13 [in Russian]. 
3. Gubaydullina, I.N., \& Ishmeyeva, A.S. (2015). Ekologicheskiy uchet kak faktor ekonomicheskoy bezopasnosti khozyaystvuyushchego sub'yekta [Ecological accounting as a factor of an economic entity's security]. Sovremennyye problemy nauki i obrazovaniya - Modern problems of science and education, 1-1 [in Russian].

4. Il'icheva, Ye.V. (2009). Sravnitel'naya kharakteristika finansovogo, nalogovogo, upravlencheskogo i ekologicheskogo ucheta [Comparative characteristics of financial, tax, managerial and ecological accounting]. Fundamental'nyye issledovaniya - Fundamental researches, 1, 66-67 [in Russian].

5. Kirsanova, T.A., \& Kirsanova Ye.V., \& Luk'yanikhin V.A. (2004). Ekologicheskiy kontrolling - instrument ekomenedzhmenta [Ecological controlling as a managerial tool]. Sumy: Izd-vo «Kozats'kyj val» [in Russian].

6. Pelinyo, L.M. (2008). Místse ekologíchnogo obliku v suchasnij systemi bukhgalters'kogo obliku ta yogo vazhlyve znachennya $\mathrm{v}$ sferi okhoroni dovkillya [A place of ecological accounting in the modern accounting system and its importance in the field of ecological protection]. Naukovyj visnyk NLTU Ukrainy - Scientific Bulletin of NLTU of Ukraine, 18.2, 70-75 [in Ukrainian].

7. Rubanova, N.N. (2005). Ekologicheskiy uchet na predpriyatiyakh promyshlennosti stroitel'nykh materialov [Ecological accounting at the enterprises of the building materials industry]. Extended abstract of candidate's thesis. Stavropol [in Russian].

8. Sayenko, K.S. (2005). Uchet ekologicheskikh zatrat [Accounting of ecological costs]. M.: Finansy i statistika [in Russian].

Одержано 11.09.2018 p. 